\title{
Inhaled corticosteroids in childhood asthma: the story continues
}

\author{
Wim M. C. van Aalderen • Aline B. Sprikkelman
}

Received: 23 August 2010 / Accepted: 20 September 2010/Published online: 8 October 2010

(C) The Author(s) 2010. This article is published with open access at Springerlink.com

\begin{abstract}
Inhaled corticosteroids (ICS) are the most effective anti-inflammatory drugs for the treatment of persistent asthma in children. Treatment with ICS decreases asthma mortality and morbidity, reduces symptoms, improves lung function, reduces bronchial hyperresponsiveness and reduces the number of exacerbations. The efficacy of ICS in preschool wheezing is controversial. A recent task force from the European Respiratory Society on preschool wheeze defined two different phenotypes: episodic viral wheeze, wheeze that occurs only during respiratory viral infections, and multiple-trigger wheeze, where wheeze also occurs in between viral episodes. Treatment with ICS appears to be more efficacious in the latter phenotype. Small particle ICS may offer a potential benefit in preschool children because of the favourable spray characteristics. However, the efficacy of small particle ICS in preschool children has not yet been evaluated in prospective clinical trials. The use of ICS in school children with asthma is safe with regard to systemic side effects on the hypothalamic-pituitary-adrenal axis, growth and bone metabolism, when used in low to medium doses. Although safety data in wheezing preschoolers is limited, the data are reassuring. Also for this age group, adverse events tend to be minimal when the ICS is used in appropriate doses.
\end{abstract}

Keywords Inhaled corticosteroids · Asthma Children · Preschool $\cdot$ Safety $\cdot$ Wheeze

\footnotetext{
W. M. C. van Aalderen $(\bowtie) \cdot A$. B. Sprikkelman

Department of Paediatric Respiratory Medicine and Allergy, Emma Children's Hospital AMC,

Meibergdreef 9,

1105AZ Amsterdam, The Netherlands

e-mail: w.m.vanaalderen@amc.nl

A. B. Sprikkelman

e-mail: a.b.sprikkelman@amc.nl
}

\section{Introduction}

Inhaled corticosteroids (ICS) are the cornerstone of asthma treatment in adults and children. They remain the most effective anti-inflammatory drugs for the treatment of persistent asthma. Since their introduction in the early 1970s, no other equally effective drug for asthma treatment has become available, and this will probably remain so for the foreseeable future. Treatment with ICS has decreased asthma mortality and morbidity [61]. In addition, treatment with ICS reduces symptoms, improves lung function, reduces the degree of bronchial hyperresponsiveness (BHR) and reduces the number of exacerbations [1-3]. ICS treatment improves the burden of asthma by decreasing the number of nocturnal awakenings due to respiratory symptoms, by reducing school absence and, especially valuable for children, by helping to enable participation in sports and other social activities [60].

The goal of asthma therapy for children is to achieve asthma control by optimising lung function, reducing day and night time symptoms, reducing limitations in daytime activities and the need for reliever treatment and by reducing asthma exacerbations [27]. However, especially in children, it is of importance to achieve control with a minimum of side effects of medication.

Guidelines from all countries advocate the use of ICS for the treatment of persistent asthma. Due to the efficacy of ICS as a class, low- to medium-dose ICS treatment outweighs the potential risks of adverse effects [53]. Recent Global Initiative for Asthma Guidelines recommend lowdose ICS (low-to-medium dose 100-200 $\mu \mathrm{g}$ beclomethasone dipropionate (BDP) equivalent twice daily or 125$250 \mu \mathrm{g}$ fluticason twice daily) therapy when asthma symptoms requiring a short-acting beta ${ }_{2}$-agonist occur more than once per week (but less than daily; step 2) and as 
baseline therapy with various adjunctive therapies for more severe disease (steps 3 and 4) [27]. In children 5 years of age or younger, low-dose ICS is advocated in partly controlled asthma, with a doubling of the dose for those with uncontrolled asthma or asthma that is partly controlled on a low-dose of ICS (see Fig. 1).

ICS therapy for asthma, especially for children, has changed substantially since the introduction of the first ICS, BDP, in the early 1970s, followed soon thereafter by budesonide (BUD). Over the last two decades, a number of novel ICS, such as fluticasone propionate (FP), as well as the small particle ICS ultrafine hydrofluoroalkane (HFA)BDP and ciclesonide, have entered the market. In addition to improvements in the ICS molecules available for the treatment of asthma, our understanding of the importance of the deposition characteristics of these drugs in determining safety and efficacy has increased. Finally, there have been significant advances in inhaler technology, and this too can impact the effectiveness of an ICS. The purpose of this review, therefore, is to provide an updated overview of relevant studies in children of school age as well as in preschool children with respect to the efficacy, safety and lung delivery of ICS.

\section{History}

In 1936, cortisone, initially called compound E, was for the first time extracted from the renal cortex by Edward Kendal at the Mayo Clinic. In 1950, the first report on successful use of cortisone in asthma was published, followed soon thereafter by a confirmatory clinical trial $[16,58]$. Despite its apparent efficacy, it became obvious that the adverse effects following long-term treatment were substantial. Hypertension, diabetes mellitus, osteoporosis, obesity, facial mooning, acne, skin thinning and bruising, the development of glaucoma and, especially in children, growth retardation were some of the severe complications of this relatively new treatment option. Search for safer compounds and safer modes of administration of corticosteroids led to the introduction of inhaled BDP in the 1970s, which, based on evidence from clinical trials, was administered four times per day, following initial approval. Subsequently, Willey et al. showed that twice daily administration of the new corticosteroid, BUD $(200 \mu \mathrm{g}$ twice daily), was as effective as four times daily therapy [74]. Based on these data, as well as patient preference, twice daily dosing became the standard regimen for all ICS with the exception of ciclesonide and budesonide in mild asthma, which can be administered by inhalation once daily. However, it is important to note that ciclesonide is not approved for once daily use in some countries such as the USA.

Inhaled corticosteroids also became the standard of care for the treatment of asthma in children after it had been convincingly demonstrated that treatment of the underlying airway inflammatory processes provided overall asthma control that was far superior to bronchodilator treatment alone. In children aged 7-16 years, Van Essen-Zandvliet et al. [67] showed that the effects of chronic treatment with BUD $(100 \mu \mathrm{g}$ administered three times per day for 22 months) was far superior to chronic treatment with the short acting $\beta_{2}$ adrenergic drug, salbutamol (200 $\mu \mathrm{g}$ administered three times per day), with respect to asthma symptoms, lung function, degree of BHR and frequency of exacerbations. Eight years later, these results were confirmed in a much larger population of school children (aged 5-12 year) in the USA with mild to moderate persistent asthma who received $200 \mu \mathrm{g}$ budesonide, $8 \mathrm{mg}$ nedocromil, or placebo twice daily for 4-6 years [64]. The results of these and other paediatric asthma studies provide a solid foundation for our current understanding of ICS and their role in the treatment of paediatric asthma, and one may conclude that inhaled corticosteroid treatment is very effective in school-aged children.

Despite the introduction of other classes of medications for children with asthma in the last decades, ICSs continue to be the recommended first-line maintenance therapy for
Fig. 1 Gina guidelines for children 5 years and younger

\begin{tabular}{|c|c|c|c|}
\hline \multicolumn{4}{|c|}{$\begin{array}{l}\text { GINA Asthma management approach based on control } \\
\text { for children } 5 \text { years and younger }\end{array}$} \\
\hline \multicolumn{4}{|c|}{ Asthma education, Environmental Control, as needed $\beta 2$ agonists } \\
\hline \multicolumn{2}{|c|}{$\begin{array}{l}\text { Controlled on as needed rapid- } \\
\text { acting } \beta_{2} \text {-agonists }\end{array}$} & $\begin{array}{c}\text { Partly controlled on } \\
\text { as needed rapid-acting } \\
\beta_{2} \text {-agonists }\end{array}$ & $\begin{array}{l}\text { Uncontrolled or only partly controlled } \\
\text { on as needed } \\
\text { rapid-acting } \beta_{2} \text {-agonists }\end{array}$ \\
\hline \multicolumn{4}{|c|}{ Controller options } \\
\hline \multirow[t]{2}{*}{$\begin{array}{l}\text { Continue as needed } \\
\text { rapid acting } \beta 2 \text { agonists }\end{array}$} & & dose inhaled corticosteroid & $\begin{array}{l}\text { Double low-dose inhaled } \\
\text { corticosteroid }\end{array}$ \\
\hline & & Leukotriene modifier & $\begin{array}{c}\text { Low-dose inhaled } \\
\text { corticosteroid plus Leukotriene } \\
\text { modifier }\end{array}$ \\
\hline
\end{tabular}


paediatric asthma patients in numerous national and international asthma treatment guidelines. For example, inhaled, long-acting beta 2 -agonists (LABA) were introduced approximately 20 years ago. Early studies with LABAs in children showed little or no benefit when these agents were added to a maintenance regimen that included an ICS [51,70]. A more recent systematic review in adults and children [54] showed that the addition of LABA to an ICS in patients who are symptomatic on low to high doses of ICS reduces the rate of exacerbations requiring systemic corticosteroids, improves lung function and asthma symptoms and reduces the use of rescue short-acting beta $2^{-}$ agonists. However, when only paediatric studies were included in the analyses [55], the addition of a LABA to an ICS was not associated with a significant reduction in the rate of exacerbations requiring systemic corticosteroids but was associated with a significant improvement in lung function compared with an ICS alone. Similarly, compared with a double dose of ICS, the combination of a LABA and a lower dose of ICS did not significantly decrease the risk of exacerbations requiring oral corticosteroids, but it did result in significantly greater improvements in peak expiratory flow and caused significantly less growth impairment [55].

A major new class of asthma treatments introduced within the past 15 years belongs to the class of agents referred to as leukotriene-modifying drugs. As a class, these agents did not have a major impact on treatment outcomes in paediatric asthma. A dose of $400 \mu \mathrm{g}$ /day of BDP or equivalent ICS appeared to be more effective than the usual approved doses of anti-leukotriene agents [23]. In addition, the use of anti-leukotrienes as add-on therapy to ICS leads, at most, to modest improvements in lung function, and overall asthma control often deteriorates when the ICS is tapered or discontinued [22].

Despite the introduction of other classes of asthma medication, ICS remain the most important anti-asthma therapy in school children with asthma.

\section{Inhaled corticosteroids in preschool children}

Population studies have shown that one in three children will have at least one episode of wheezing before they reach their third birthday, rising to almost one in two (50\%) by age $6[30,49]$. Unfortunately, the ability to predict who among these children will have transient versus persistent problems is poor. As such, epidemiological data, such as these, has limited clinical applicability. In this regard, prospective studies in which subjects were also phenotyped using a number of different clinical measures (e.g., lung function, BAL, etc.) showed considerable overlap between these groups [13]. Therefore, at present, there are no diagnostic tools that can reliably predict the development of asthma among wheezy infants.

Noisy breathing is common among infants. It is important to note that it is difficult for parents to recognise wheezing, and accurately identifying wheezing by medical history is virtually impossible, as the term is used by parents and doctors to describe a variety of symptoms [15]. Children with physician-confirmed wheezing have higher airway resistance than children with parent-reported wheeze [47]. It may be that physician-confirmed wheezing can become important as a predictor for the development of asthma at older age. We observed that preschool children with an increased specific IgE and who also wheezed had a substantially increased chance of developing asthma by the time they reached school age [25]. Unfortunately, in this study, wheezing was not reported by a physician. Devulapalli et al. demonstrated that a high severity score of obstructive airways disease by 2 years of age is a strong risk factor for, and may predict, current asthma at 10 years of age [19]. Bronchial biopsies obtained from infants with confirmed wheezing have shown increased thickness of the reticular basal membrane and significantly greater eosinophilic inflammation compared with samples from children with parent-reported wheezing or control subjects [59].

Early identification of asthma is mandatory in school children since early treatment in this age group can prevent exacerbations and deterioration of lung function. However, in preschool children, no such data are available. Recent early intervention studies with ICS in young children aimed at the prevention of asthma have shown no beneficial results with respect to the development of asthma $[11,29,52]$, and the results of therapeutic studies are conflicting.

Episodic viral wheeze [13]

Episodic viral wheeze has been defined recently by a European Respiratory Society task force to describe children who wheeze intermittently and are well between episodes. The efficacy of ICS in the treatment for episodic viral wheeze in preschool children is controversial. The majority of asthma exacerbations in school-aged children are associated with viral infections [35], and this also holds true for the majority of wheezing episodes in preschool children [77]. Intermittent versus daily ICS treatment in children was reviewed by the Cochrane Airways Group [50]. Studies in children up to 17 years of age were included, but the review also contained studies conducted in preschool children. This review showed that children benefited from intermittent use of high-dose ICS $(1,600$ $3,200 \mu \mathrm{g} /$ day BDP or BUD) as evidenced by a reduction in the severity of symptoms. There was also a trend for 
reduced requirements of oral corticosteroids. More recently, a controlled, randomised, double-blind clinical trial of $750 \mu \mathrm{g}$ FP versus placebo twice daily in 129 children who were 1-6 year of age with recurrent virus-induced wheezing showed a reduction in the use of rescue oral corticosteroids in the FP-treated patients [24]. However, treatment with FP was associated with a smaller gain in height and weight. Among preschool children, no benefit was shown for continuous low-dose ICS treatment $(400 \mu \mathrm{g} / \mathrm{day}$ BUD) with respect to a reduction in the number or the severity of wheezing episodes [75]. Finally, a double-blind, placebo-controlled, randomised interventional study, primarily designed to assess whether or not treatment with intermittent courses of inhaled budesonide (400 $\mu \mathrm{g} /$ day) versus placebo for 2 weeks during wheezing episodes could delay progression to persistent wheezing, did not show any benefit of ICS during the first 3 years of life [11].

Maintenance treatment with ICS in episodic viral wheeze in low-to-medium dosage seems not beneficial. Intermittent treatment with high-dose ICS during wheezing episodes has some beneficial effects but increases the risk of systemic side effects. An alternative possibility for this phenotype is treatment with montelukast, which reduced the rate of wheezing episodes in 549 preschool children with episodic viral wheeze by $32 \%$ compared to placebo [12].

\section{Multiple-trigger wheeze [13]}

Multiple-trigger wheeze has been defined recently by a European Respiratory Society task force to describe children who wheeze both during and outside discrete episodes. The treatment of preschool children with multiple-trigger wheeze with ICS appears to be more successful than that of children with episodic viral wheeze. Children with multiple-trigger wheeze often develop symp- toms after crying, laughter or exercise. Based on these findings, many believe that multiple-trigger wheeze resembles allergic asthma, but there is little direct evidence to support this. It remains unknown whether the histopathology of the airways from children with multiple-trigger wheeze resembles that of allergic asthma. However, a proportion of preschoolers with persistent wheeze do develop asthma in later life $[49,78]$.

Kaditis et al. [37] and Castro-Rodriguez et al. [17] reviewed the literature on the efficacy of ICS in recurrent wheezing preschool children. Based on these systematic reviews, as well as a number of randomised, double-blind, placebo-controlled clinical trials published after this review was completed, it is concluded that continuous treatment with ICS decreases the number of days with symptoms among children with persistent wheezing, without preventing the need for hospitalisation [14] and had less wheezing/ asthma exacerbations and improved their symptoms and lung function, respectively [17].

There is solid evidence that maintenance treatment with a low-to moderate dose of ICS decreases the number of days with asthma symptoms in children with multipletrigger wheeze. However, Kaditis et al. [37] questioned whether the relative benefit of continuous treatment with ICS (approximately 5\% fewer symptom-free days versus placebo) is clinically significant and outweighs the possible side effects. Montelukast improved symptoms and achieved a $30 \%$ reduction in exacerbations in 689 preschool children with multiple-trigger wheeze [41], but head-to-head comparisons with an inhaled corticosteroid are not available in the literature [7,13] (Table 1).

Newer, small particle ICS, such as ultrafine HFA-BDP aerosol (QVAR) and ciclesonide, may offer a potential benefit in preschool children. This resulted in a recommendation in the revised Dutch Paediatric Asthma Guidelines 2007 to treat children under 6 years with a small particle ICS [32]. This recommendation is primarily based on a

Table 1 Characteristics of episodic viral wheeze and of multiple-trigger wheeze

\begin{tabular}{|c|c|c|}
\hline & Episodic viral wheeze & Multiple-trigger wheeze \\
\hline Definition & $\begin{array}{l}\text { Wheezing during discrete time periods, often in } \\
\text { association with clinical evidence of a viral cold }\end{array}$ & $\begin{array}{l}\text { Wheezing that shows discrete exacerbations } \\
\text { but also symptoms between episodes }\end{array}$ \\
\hline Triggers & Viral infections & $\begin{array}{l}\text { Viral infections, tobacco smoke, allergen } \\
\text { exposure, mist exposure, crying, exercise }\end{array}$ \\
\hline Possible underlying factors & $\begin{array}{l}\text { Pre-existent impaired lung function, } \\
\text { tobacco smoke exposure, prematurity, atopy }\end{array}$ & Eosinophilic inflammation? \\
\hline Continues treatment with ICS & Little or no benefit & Significant fewer days with symptoms \\
\hline Treatment with montelukast & Moderate benefit & Moderate reduction in exacerbations \\
\hline Long-term outcome & $\begin{array}{l}\text { Declines over time ( }<6 \text { year), can continue as } \\
\text { episodic viral wheeze into school age, can } \\
\text { change in multiple-trigger wheeze }\end{array}$ & Can continue as asthma into adulthood \\
\hline
\end{tabular}


model-deposition study that is outlined below. The average particle size is smaller [median mass aerodynamic diameter (MMAD) of both compounds is $1.1 \mu \mathrm{m}]$, the velocity of the particles leaving the inhaler on actuation is slower, the duration of the spray is longer and the temperature of the spray is warmer compared with that of traditional inhalers [42]. As a result, a softer more gentle spray is produced, fewer particles impact on the oropharynx and more drug reaches the lung, particularly the small airways [43]. These improved delivery characteristics may be particularly relevant for young children in whom a greater proportion of airways are classified as small (i.e. $<2 \mathrm{~mm}$ in diameter) and airways resistance is low [68].

In adults with asthma, ultrafine HFA-BDP aerosol provides equivalent asthma control at half the daily dose of conventional chlorofluorocarbon (CFC)-BDP [18]. Two clinical studies with ultrafine HFA-BDP were performed in school children with asthma $[62,66]$. The first was a 6month, open-label, randomised clinical trial that confirmed that asthma control can be well maintained in children aged 5-11 years when switching from a conventional CFC-BDP metered dose inhaler (MDI) inhaled via a spacer to ultrafine HFA-BDP (administered via an Autohaler ${ }^{\circledR}$ ) at doses as low as $100-200 \mu \mathrm{g} /$ day [62]. A randomised controlled, double-blind, double-dummy clinical trial in school children aged 5-12 years with mild-moderate asthma showed that ultrafine HFA-BDP MDI and CFC-fluticasone MDI were equally effective in improving asthma control in children with mild-moderate asthma at the same daily dose and that the majority of children in both groups could reduce their daily dose to as low as $50 \mu \mathrm{g}$ /day while maintaining good asthma control [66]. In 2008, a Cochrane Systemic Review compared ciclesonide with other inhaled corticosteroids in children and adults with asthma [48]. The majority of the studies were performed in asthma patients from 12 to 75 years of age. Three of the studies were performed in children, aged 6-11, 12-17 and 6-11 years, respectively $[57,71,73]$. In 6-11-year-old children, a randomised, double-blind, double-dummy, three-arm, parallel group study showed that once daily ciclesonide (80 or $160 \mu \mathrm{g}$ daily) administered via a MDI without a spacer had a clinical effect similar to that of FP $(100 \mu \mathrm{g}$ twice daily) administered via a MDI [57]. The two other studies compared the efficacy of ciclesonide (320 and $160 \mu \mathrm{g}$ once daily, respectively) with BUD (800 $\mu \mathrm{g}$ and $400 \mu \mathrm{g}$ once daily, respectively). These studies were conducted over a period of 12 weeks in children with asthma ages 12-17 and 6-11 years, respectively, and the results showed similar efficacy with ciclesonide and BUD in a 1:2 dose ratio $[71,74]$.

Unfortunately, the efficacy of small particle inhaled corticosteroids in preschool children has not yet been evaluated in prospective clinical trials. This is the reason that HFA-BDP in The Netherlands is registered from the age of 5 years and older. This is in contrast with the recommendation in the revised Dutch Paediatric Asthma Guidelines 2007 [32]. The only study that suggests that small particle ICS may have an advantage in very young children is an infant model study. In an anatomically correct model of the upper airway of a 9-month-old infant, the SAINT model [33], lung deposition of CFC-BDP (MMAD 3.5-4.0 $\mu \mathrm{m}$ ) and ultrafine HFA-BDP (MMAD, $1.1 \mu \mathrm{m}$ ) was compared. The SAINT model was connected to a breathing simulator and a cascade impactor. This study showed that lung doses for ultrafine HFA-BDP were 25.4 $30.7 \%$ over the range of tidal volumes evaluated (50$200 \mathrm{ml}$ ), while the lung doses for CFC-BDP ranged from $6.8 \%$ to $2.1 \%$ [34]. The deposition of the small particles was relatively independent of tidal volume, which may be a theoretical advantage in young children. This study suggests that ultrafine HFA-BDP will be delivered in an increased lung dose in preschool children compared with an ICS that has a higher MMAD. However, these data must be interpreted with the caveat that drug delivery for individual patients in clinical practice also depends on other factors such as the inhalation technique and the cooperation of the child (Table 2).

\section{Adverse effects}

Local adverse effects of inhaled corticosteroids, such as hoarseness as well as oral candidiasis, may cause serious discomfort in children, although these adverse effects are less common than in adults.

Due to the well-known adverse effects of systemic corticosteroids, there is general awareness of the potential for adverse systemic effects with ICS as well, especially when they are administered at high doses for extended periods of time. Adverse systemic effects of ICS have been reviewed extensively $[8,39,40,44,45,56,65]$. All corticosteroid actions are mediated through the stimulation of glucocorticosteroid receptors in the cytoplasm of cells throughout the tissues. However, there is widespread heterogeneity in both the efficacy as well as the systemic safety of ICSs among individuals with asthma, even when using the same doses of ICS. This variability in response is multifactorial and includes environmental and genetic factors [39].

Principal methods for reducing systemic activity include reducing the bioavailability of the ICS from the gastrointestinal tract and prolonging residence time of the ICS in the lung tissue. Improving drug delivery to the lungs by a better inhalation device may also result in higher systemic availability of the ICS. Therefore, the efficacy and adverse effects of an ICS are coupled with the delivery device. The 
Table 2 Current knowledge on ICS

\begin{tabular}{|c|c|c|}
\hline What is known & What is new & What is uncertain \\
\hline $\begin{array}{l}\text { ICs are the cornerstone of asthma } \\
\text { treatment }\end{array}$ & $\begin{array}{l}\text { Early intervention with ICS } \\
\text { does not prevent the } \\
\text { development of asthma }\end{array}$ & $\begin{array}{l}\text { VEW and MTW are distinct } \\
\text { phenotypes }\end{array}$ \\
\hline $\begin{array}{l}\text { ICS reduce symptoms, improve lung } \\
\text { function and prevent deterioration of } \\
\text { lung function over time, improves BHR, } \\
\text { reduces exacerbations in school aged } \\
\text { children }\end{array}$ & Phenotypes VEW and MTW & MTW=asthma \\
\hline \multirow[t]{3}{*}{ ICS are safe in low to moderate dose } & $\begin{array}{l}\text { ICS in EVW not efficacious, } \\
\text { but more effective in MTW }\end{array}$ & $\begin{array}{l}\text { Physicians confirmed } \\
\text { wheezing predictive for } \\
\text { asthma }\end{array}$ \\
\hline & MTW resembles asthma & $\begin{array}{l}\text { No clinical studies with } \\
\text { small particle ICS in } \\
\text { preschool children }\end{array}$ \\
\hline & $\begin{array}{l}\text { Parent reported wheeze is } \\
\text { unreliable }\end{array}$ & $\begin{array}{l}\text { No head to head studies } \\
\text { ICS vs montelukast in } \\
\text { preschool children }\end{array}$ \\
\hline
\end{tabular}

ICS inhaled corticosteroids, $V E W$ viral episodic wheeze, $M T W$ multiple-trigger wheeze, $B H R$ bronchial hyperresponsiveness to be related to the administration of very high doses of an ICS for prolonged periods of time. For example, Drake et al. described four case reports of adrenal insufficiency (presenting as hypoglycaemia) reported in children with asthma who had received high doses (500-1,500 $\mu \mathrm{g} /$ day; maximum approved dose in children under the age of 12 is $200 \mu \mathrm{g} /$ day in most countries) of FP for 6 months or longer [21].

Growth and inhaled corticosteroids

In 1998, an FDA advisory committee reviewed the available data on growth in children following treatment with ICS and intranasal corticosteroids. The advisory committee concluded that growth suppression was a class effect that occurred with low to medium doses of corticosteroids, even when these doses did not produce impairment of other measures of HPA axis function [36].

With the FDA advisory committee findings in mind, it is important to recognise that like other measures of HPA axis function, the more sensitive the growth measure, the less clinically relevant it appears to be. For example, initial knemometry studies demonstrated a significant and dosedependent effect of ICS on lower leg growth velocity retardation [76], but these effects did not predict effects of ICS, if any, on the final height of children. The same was found to be true in year-long studies with the inhaled corticosteroid, CFC-BDP MDI [20,69]. In two separate, randomised, double-blind, placebo-controlled clinical trials with $200 \mu \mathrm{g}$ CFC-BDP twice daily or placebo in school children ages 6-16 and 7-9 years, respectively, with asthma, a median growth retardation of approximately $1 \mathrm{~cm}$ was observed in the intervention groups relative to placebo. This small transient reduction in growth velocity 
was also observed in the CAMP study, where 1,041 children from 5 to 12 years of age with mild to moderate asthma were randomised to $200 \mu \mathrm{g}$ BUD, $8 \mathrm{mg}$ nedocromil, or placebo twice daily. The children were treated for 4-6 years [64]. However, final height in adulthood among children following long-term treatment with inhaled corticosteroids appears to be comparable to that of children with asthma who were not treated with an ICS [4]. These studies indicate that low to moderate dosages of ICS are safe with respect to growth.

Bone metabolism and inhaled corticosteroids

In adults, extensive data are available on the adverse effects of ICS on bone metabolism, including osteoporosis and fractures. Inhibition of bone metabolism by ICS could have important long-term consequences, particularly in women where reductions in bone mass may ultimately result in osteoporosis and an increased incidence of bone fractures at older ages. There is, however, continuing debate as to whether a total cumulative dose or a specific daily dose range is the best predictor of bone loss.

The adverse effects of ICS on bone mineral density and bone metabolism in children with asthma are not well defined, but effects do appear to be dose related. Six months of high-dose treatment with $1,000 \mu \mathrm{g}$ of FP in children aged 5-19 years did not result in a significant reduction in bone metabolism or bone mineral density [28]. This is in contrast with an earlier study over a period of 1 year that showed a change in bone mineral content in children aged 5-14 years treated with high doses of BDP or BUD (range of doses, 400-2,000 $\mu \mathrm{g} /$ day) [6]. Similarly, a step-down study in children aged 6-10 years who were treated with FP $(1,000 \mu \mathrm{g} /$ day $)$ for 2 months showed a reduction in bone metabolism and lower leg growth velocity, as well as HPA axis suppression [72]. However, all adverse effects observed in the initial high-dose FP treatment period disappeared after dose reduction. It is also important to note that direct measurements on bone, as well as measures of bone biomarkers, show no evidence that low to medium doses of ICS effect bone density [5]. In this regard, the CAMP study [64], where children aged 5-12 years at study entry were treated for 46 years with $400 \mu \mathrm{g} /$ day of budesonide DPI, found no evidence that long-term BUD treatment affected bone mineral density.

Adverse effects in preschool children

There is limited safety data on ICS in very young children, but the data that are available are reassuring. Lødrup Carlsen et al. showed in a randomised, multi- center, placebo-controlled, parallel group study of children ages 12-47 months, who were treated with either $100 \mu \mathrm{g}$ of FP or placebo twice daily for 12 weeks, that FP was well tolerated, and the overall adverse event profile was similar in the two groups [46]. Urinary cortisol/creatinine ratios were slightly decreased among FP patients after 12 weeks, but there were no adverse events linked to HPA-axis suppression in this study. Another randomised, double-blind, placebo-controlled, parallel-group trial in infants aged 6-12 months receiving 0.5 or $1.0 \mathrm{mg}$ of BUD as a nebulised suspension, or placebo, for 12 weeks showed that the safety profile of BUD suspension was similar to that of placebo, with no suppressive effects on adrenal function [9]. More recently, daily treatment with inhaled $250 \mu \mathrm{g}$ FP (administered as $125 \mu \mathrm{g}$ via a MDI with a spacer two times daily) for 18 months in children with a mean age 10 months who had recurrent wheeze and a family history of asthma was shown to have no adverse effects on the HPA axis or on linear growth [31]. However, FP treatment was associated with increases in body weight and body mass index. These results are consistent with earlier studies in 471 children aged $1-3$ years who received $200 \mu \mathrm{g}$ FP (administered as $2 \times 50 \mu \mathrm{g}$ via a MDI with a spacer two times daily) for 52 weeks and 40 children under 2 years of age who were randomised to either $100 \mu \mathrm{g}$ or $250 \mu \mathrm{g}$ of FP (adminsistered as one single puff via a MDI with a spacer two times daily) or placebo for 6 months $[10,63]$. Guilbert et al. conducted a clinical study in 2-3-year-old children who received FP $200 \mu \mathrm{g} / \mathrm{day}$ (administered as two $50-\mu \mathrm{g}$ puffs via an MDI with a spacer two times daily) or placebo for 2 years and showed that there was a mean difference of $-1.1 \mathrm{~cm}$ from placebo in height at the end of the 2-year treatment period [21]. In this same study, a $-0.7 \mathrm{~cm}$ difference in height from placebo was observed 1 year following the cessation of study medication [29]. The authors questioned, however, whether height would have become similar in the two groups as the cohort matured. Finally, in the IFWIN study, children aged $0.5-4.9$ years were randomised to receive $200 \mu \mathrm{g}$ FP (administered as $100 \mu \mathrm{g}$ via a MDI with a spacer twice daily) or placebo [52]. After 6 months, the FP group had a decrease in Zscore (the height standard deviation scores calculated from the UK 1990 reference curves). [26,78] At 5 years of age, both the FP and the placebo groups had similar changes in $\mathrm{Z}$-scores relative to the pre-treatment Z-scores. All FPtreated children had received treatment for at least 9 months. The temporary reduction in growth in the FP group is comparable to the effects observed in school children with asthma. Together, these data show that with respect to growth, ICS are well tolerated and have minimal or no long-term effects on growth when used in appropriate doses. 


\section{Conclusions}

Inhaled corticosteroids remain the most effective antiinflammatory therapy for the treatment of adults and school-aged children with asthma. The efficacy of ICS in preschool children with episodic viral wheeze remains controversial, while ICS treatment of preschool children with multiple-trigger wheeze appears to be at least somewhat effective. However, the effect size in preschool children with multiple-trigger wheeze is smaller than the effect size in school-aged children with asthma.

In school children with asthma, small-particle ICSs, such as ultrafine HFA-BDP and ciclesonide, are as effective as fluticasone propionate on a microgram for microgram basis, and at least as effective, at half the dose, as BUD and CFCBDP. The small particle ICSs appear to have theoretically a very favourable benefit/risk ratio in preschool children, but prospective clinical studies with these ICS in this age group are needed. ICS are generally well tolerated in both school-aged and preschool children, and adverse events tend to be minimal in both age groups when the ICS is used in appropriate doses.

Open Access This article is distributed under the terms of the Creative Commons Attribution Noncommercial License which permits any noncommercial use, distribution, and reproduction in any medium, provided the original author(s) and source are credited.

\section{References}

1. Adams NP, Bestall JC, Jones PW (1999) Budesonide versus placebo for chronic asthma in children and adults. In: The Cochrane library, issue 4. Wiley, Chichester

2. Adams NP, Bestall JC, Malouf R et al (2005a) Beclomethasone versus placebo for chronic asthma. Cochrane Database Syst Rev (1):CD002738

3. Adams NP, Bestall JC, Lasserson TJ et al (2005b) Fluticasone versus placebo for chronic asthma in adults and children. Cochrane Database Syst Rev (4):CD003135

4. Agertoft L, Pedersen S (2000) Effect of long-term treatment with inhaled budesonide on adult height in children with asthma. $\mathrm{N}$ Engl J Med 343:1064-1069

5. Allen DB (2002) Safety of inhaled corticosteroids in children. Pediatr Pulmonol 33:208-220

6. Allen HD, Thong IG, Clifton-Bligh P et al (2000) Effects of highdose inhaled corticosteroids on bone metabolism in prepubertal children with asthma. Pediatr Pulmonol 29:188-193

7. Bacharier LB (2008) Management of asthma in preschool children with inhaled corticosteroids and leukotriene receptor antagonists. Curr Opin Allergy Clin Immunol 8:158-162

8. Barnes PJ, Pedersen S, Busse WW (1998) Efficacy and safety of inhaled corticosteroids: new developments. Am J Respir Crit Care Med 157(Suppl):S1-S53

9. Berger WE, Qaqundah PY, Blake K et al (2005) Safety of budesonide inhalation suspension in infants aged 6 to 12 months with mild to moderate persistent asthma or recurrent wheeze. J Pediatr 146:91-95
10. Bisgaard H, Allen D, Milanovski J et al (2004) Twelve months safety and efficacy of inhaled fluticasone propionate in children aged 1-3 years with recurrent wheezing. Pediatrics 113:87-94

11. Bisgaard H, Hermansen MN, Loland L et al (2006) Intermittent inhaled corticosteroids in infants with episodic wheezing. N Engl J Med 11(354):1998-2005

12. Bisgard H, Zielen S, Garcia-Garcia ML et al (2005) Montelukast reduces asthma exacerbations in 2- to 5 year old children with intermittent asthma. Am J Respir Crit Care Med 171:315-322

13. Brand PL, Baraldi E, Bisgaard H et al (2008) Definition, assessment and treatment of wheezing disorders in preschool children: an evidence-based approach. Eur Respir J 32:1096-1110

14. Calpin C, MacArthur C, Stevens D et al (1997) Effectiveness of prophylactic inhaled steroids in childhood asthma: a systematic review of the literature. J Allergy Clin Immunol 100:452-457

15. Cane RS, McKenzie SA (2000) Parents' interpretation of childrens' respiratory symptoms on video. Arch Dis Child 82:27-32

16. Carryer HM (1950) The effect of cortisone on bronchial asthma and hay fever occurring in subjects insensitive to ragweed pollen. J Allergy 21:282-286

17. Castro-Rodriguez JA, Rodrigo GJ (2009) Efficacy of inhaled corticosteroids in infants and preschoolers with recurrent wheezing and asthma: a systematic review with meta analysis. Pediatrics 123:e519-e 525

18. Davies RJ, Stampone P, O’Connor BJ (1998) HFA-134a beclomethasone dipropionate extrafine aerosol provides equivalent asthma control to CFC beclomethasone dipropionate at approximately half the total daily dose. Respir Med 92(suppl A):23-31

19. Devulapalli CS, Carsen KCL, Haland G et al (2008) Severity of obstructive airways disease by age 2 years predicts asthma at 10 years of age. Thorax 63:8-13

20. Doull IJ, Freezer NJ, Holgate ST (1995) Growth of prepubertal children with mild asthma treated with inhaled beclomethasone dipropionate. Am J Respir Crit Care Med 151:1715-1719

21. Drake AJ, Howells RJ, Shield JPH et al (2002) Symptomatic adrenal insufficiency presenting with hypoglycaemia in children with high dose fluticasone propionate. BMJ 324:1081-1083

22. Ducharme FM (2004) Addition of anti-leukotriene agents to inhaled corticosteroids for chronic asthma. Cochrane Database Syst Rev (1):CD003133. doi:10.1002/14651858.CD003133.pub2

23. Ducharme FM, di Salvio F (2004) Anti-leukotriene agents compared to inhaled corticosteroids in the management of recurrent and/or chronic asthma in adults and children. Cochrane Database Syst Rev (1):CD002314. doi:10.1002/14651858. CD002314.pub2

24. Ducharme FM, Lemire C, Noya FJ et al (2009) Preemptive use of high-dose fluticasone for virus-induced wheezing in young children. N Engl J Med 360:339-353

25. Eysink PE, ter Riet G, Aalberse RC et al (2005) Accuracy of specific IgE in the prediction of asthma: development of a scoring formula for general practice. Br J Gen Pract 55:125-131

26. Freeman JV, Cole TJ, Chinn S et al (1995) Cross sectional stature and weight reference curves for the UK 1990. Arch Dis Child 73:17-24

27. GINA Report (2008) Global strategy for asthma management and prevention (updated). Available at http://www.ginasthma.org

28. Griffiths AL, Sim D, Strauss B et al (2004) Effect of high-dose fluticasone propionate on bone density and metabolism in children with asthma. Pediatr Pulmonol 31:116-121

29. Guilbert TW, Morgan WJ, Zeiger RS et al (2006) Long-term inhaled corticosteroids in preschool children at high risk for asthma. N Engl J Med 354:1985-1997

30. Hess J, De Jongste JC (1995) Epidemiological aspects of paediatric asthma. Clin Exp Allergy 34:680-685

31. Iles R, Williams RW, Deeb A et al (2008) A longitudinal assessment of the effect of inhaled fluticasone propionate 
therapy in young children with asthma. Pediatr Pulmonol 43:354-359

32. Asthma in Children (2008) Summary of the revised guidelines of the Dutch Paediatric Respiratory Group (in Dutch). Lindenbaum, Amsterdam (ISBN/EAN 978-90-9023508-0)

33. Janssen HM, De Jongste JC, Fokkens WJ (2001) The Sophia Anatomical Infant Nose-Throat (SAINT) model: a valuable tool to study aerosol deposition in infants. J Aerosol Med 14:433-441

34. Janssens HM, De Jongste JC, Hop WC et al (2003) Extra-fine particles improve lung delivery of inhaled steroids in infants. Chest 123:1083-1088

35. Johnston SL, Pattemore PK, Sanderson G et al (1995) Community study of the role of viral infections in exacerbations of asthma in 9-11 year old children. BMJ 310:1225-1229

36. Joint Pulmonary and Allergy Drug Advisory Committee/Endocrinologic and Metabolic Drug Advisory Committee (1998) Orally inhaled/intranasal corticosteroids and growth in children. In: Proceedings from the Food and Drug Administration Center for Drug Evaluation and Research, Bethesda, MD

37. Kaditis AG, Winnie G, Syrogiannopoulos GA (2007) Antiinflammatory pharmacotherapy for wheezing in preschool children. Pediatr Pulmonol 42:407-420

38. Kamada AK, Szefler SJ (1997) The safety of inhaled corticosteroid therapy in children. Curr Opin Pediatr 9:585-589

39. Kelly HW (2003) Pharmaceutical characteristics that influence the clinical efficacy of inhaled corticosteroids. Ann Allergy Asthma Immunol 91:326-334

40. Kelly HW, Nelson HS (2003) Potential adverse effects of the inhaled corticosteroids. J Allergy Clin Immunol 112:469-478

41. Knorr B, Franchi LM, Bisgaard H et al (2001) Montelukast, a leukotriene receptor antagonist for the treatment of persistent asthma in children aged 2 to 5 years. Pediatrics 108:e48

42. Leach CL (1999) Effects of formulation parameters on hydrofluoroalkane-beclomethasone dipropionate drug deposition in humans. J Allergy Clin Immunol 104:S250-S252

43. Leach CL, Davidson PJ, Boudreau RJ (1998) Improved airway targeting with the CFC-free HFA-beclomethasone metered-dose inhaler compared with CFC-beclomethasone. Eur Respir J 12:1346-1353

44. Lipworth BJ (1999) Systemic adverse effects of inhaled corticosteroid therapy: a systematic review and meta-analysis. Arch Intern Med 159:941-955

45. Lipworth BJ, Wilson AM (1998) Dose response to inhaled corticosteroids: benefits and risks. Semin Respir Crit Care Med 19:625-646

46. Lødrup Carlsen KC, Stick S, Kamin W et al (2005) The efficacy and safety of fluticasone propionate in very young children with persistent asthma symptoms. Respir Med 99:1393-1402

47. Lowe LA, Simpson A, Woodcock A et al (2005) Wheeze phenotypes and lung function in preschool children. Am J Respir Crit Care Med 171:231-237

48. Manning P, Gibson PG, Lasserson TJ (2008) Ciclesonide versus other inhaled steroids for chronic asthma in children and adults. Cochrane Database Syst Rev (2):CD007031

49. Martinez FD, Wright AL, Taussig LM et al (1995) Asthma and wheezing in the first 6 years of life. N Engl J Med 332:133-138

50. McKean M, Ducharme F (2000) Inhaled steroids for episodic viral wheeze in childhood. Cochrane Database Syst Rev 2:CD001107

51. Meijer GG, Postma DS, Mulder PG et al (1995) Long-term circadian effects of salmeterol in asthmatic children treated with inhaled corticosteroids. Am J Respir Crit Care Med 152:18871892

52. Murray CS, Woodcock A, Langley SJ et al (2006) Secondary prevention of asthma by the use of inhaled fluticason proprionate in wheezy infants (IFWIN): double-blind, randomised controlled study. Lancet 368:754-762
53. National Institutes of Health, National Heart, Lung, and Blood Institute (2007) National asthma education and prevention program. Full report of the expert panel: guidelines for the diagnosis of asthma (EPR-3). Available at http://www.nhlbi.nih. gov/guidelines/asthma

54. Ni Chroinin M, Greenstone IIG, Ducharme F et al (2005) Longacting beta2-agonists versus placebo in addition to inhaled corticosteroids in children and adults with chronic asthma. Cochrane Database Syst Rev (4):CD005535. doi:10.1002/ 14651858.CD005535

55. Ni Chroinin M, Lasserson TJ, Greenstone I et al (2009) Addition of long-acting beta-agonists to inhaled corticosteroids for chronic asthma in children. Cochrane Database Syst Rev (3):CD007949. doi:10.1002/14651858.CD007949

56. Pedersen S, O'Byrne P (1997) A comparison of the efficacy and safety of inhaled corticosteroids in asthma. Allergy 52(suppl 39): $1-34$

57. Pedersen S, Engelstätter R, Weber HJ et al (2009) Efficacy and safety of cicesonide once daily and fluticasone propionate twice daily in children with asthma. Pulm Pharmacol Ther 22:214-220

58. Report to the medical research counsel by the subcommittee of clinical trials in asthma (1956) Controlled trial of the effects of cortisone acetate in chronic asthma. Lancet 1:798

59. Saglani S, Payne DN, Zhu J et al (2007) Early detection of airway wall remodeling and eosinophilic inflammation in preschool wheezers. Am J Respir Crit Care Med 176:858-864

60. Steenhuis TJ, Landstra AM, Verberne AAPH et al (1999) When asthma interrupts sleep in children; what is the best strategy? BioDrugs 12:431-438

61. Suisa S, Ernst P (2001) Inhaled corticosteroids: impact on asthma morbidity and mortality. J Allergy Clin Immunol 107:937-944

62. Szefler SJ, Warner J, Doris Staab D et al (2002) Switching from conventional to extrafine aerosol beclomethasone dipropionate therapy in children: a 6-month, open label, randomized trial. J Allergy Clin Immunol 110:45-50

63. Teper AM, Colom AJ, Kofman CD et al (2004) Effects of inhaled fluticasone propionate in children less than 2 years old with recurrent wheezing. Pediatr Pulmonol 37:111-115

64. The Childhood Asthma Management Program Research Group (2000) Long-term effects of budesonide or nedocromil in children with asthma. N Engl J Med 343:1054-1063

65. Toogood JH (1998) Side effects of inhaled corticosteroids. J Allergy Clin Immunol 102:705-713

66. Van Aalderen WM, Price D, De Baets FM et al (2007) Beclometasone dipropionate extrafine aerosol versus fluticasone propionate in children with asthma. Respir Med 101:1585-1593

67. Van Essen-Zandvliet EE, Hughes MD, Waalkens HJ et al (1992) Effects of 22 months of treatment with inhaled corticosteroids and/or beta-2-agonists on lung function, airway responsiveness, and symptoms in children with asthma. Am Rev Respir Dis 146:547-554

68. Van Schayck CP, Donnell D (2004) The efficacy and safety of QVAR (hydrofluoroalkane-beclometasone dipropionate extrafine aerosol) in asthma (part 2): clinical experience in children. Int $\mathrm{J}$ Clin Pract 58:786-794

69. Verberne AA, Frost C, Roorda RJ et al (1997) One year treatment with salmeterol compared with beclomethasone in children with asthma. Am J Respir Crit Care Med 156:688-695

70. Verberne AA, Frost C, Duiverman EJ et al (1998) Addition of salmeterol versus doubling the dose of beclomethasone in children with asthma. The Dutch Asthma Study Group. Am J Respir Crit Care Med 158:213-219

71. Vermeulen J, Gyukovits K, Rauer H et al (2007) Randomised comparison of the efficacy and safety of ciclesonide and budesonide in adolescents with severe asthma. Respir Med 101:2182-2191 
72. Visser MJ, van der Veer E, Postma DS et al (2004) Side-effects of fluticasone in asthmatic children: no effects after dose reduction. Eur Respir J 24:420-425

73. Von Berg A, Engelstätter R, Minic P et al (2007) Comparison of the efficacy and safety of ciclesonide $160 \mu \mathrm{g}$ once daily vs budesonide $400 \mu \mathrm{g}$ once daily in children with asthma. Pediatr Allergy Clin Immunol 18:391-400

74. Wiley RF, Godden DJ, Carmichael J et al (1982) Comparison of twice daily administration of a new corticosteroid budesonide with beclomethasone dipropionate four times daily in the treatment of chronic asthma. Br J Dis Chest 76:61-66
75. Wilson N, Sloper K, Silverman M (1995) Effect of continuous treatment with topical corticosteroid on episodic viral wheeze in preschool children. Arch Dis Child 72:317-320

76. Wolthers OD, Pedersen S (1992) Controlled study of linear growth in asthmatic children during treatment with inhaled glucocorticosteroids. Pediatrics 89:839-842

77. Wright AL, Taussig LM, Ray CG et al (1989) Lower respiratory tract illness in the first year of life. Am J Epidemiol 129:1232-1246

78. Yunginger JW, Reed CE, O'Connell EJ et al (1992) A community-based study of the epidemiology of asthma. Incidence rates, 1964-1983. Am Rev Respir Dis 146:888-894 